\title{
Individual and External Catalysts and Barriers of Biking: A Community Based Study in a Metropolis
}

\author{
Veda Vakili, Lida Jarahi, Seyed Mojtaba Mousavi Bazzaz and Pardis Shojaee* \\ Department of Community Medicine, Faculty of Medicine, Mashhad University of Medical Sciences, \\ Mashhad, Iran; dr.pardis.shojaei@gmail.com
}

\begin{abstract}
Biking has proven health, environmental and traffic benefits. To prevail biking at community infrastructures and "Bicycle Sharing Systems (BSS)" have been developed, but their effectiveness is dependent on people's attitudes and perceptions. We aim to investigate attitudes of people toward biking and related infrastructures with regard to demographic factors in Mashhad, Iran-a metropolis with unsuccessful BSS. The present work was conducted as a cross-sectional study at Mashhad, Iran, in 2015. In a multistage sampling, adult inhabitants were selected and data about their perceptions of benefits and barriers of biking were collected through a researcher-designed questionnaire. Of 437 study participants with a mean $( \pm$ SD) age of $29.9( \pm 11.3)$ years, $250(57.3 \%)$ were female. Only $3(0.7 \%)$ of respondents used bikes. Positive attitudes were significantly associated with gender, marital status and occupation of participants. Car ownership was accompanied by higher perceptions of "tiredness of biking" $(\mathrm{p}=0.02)$, its "low safety" $(\mathrm{p}=0.02)$ and "time wasting" $(\mathrm{p}=0.01)$. According to the results, cultural interventions are needed for biking promotion regardless of their socioeconomic status. Educational programs at academic settings are also valuable. Safety, convenience, and affordability of different groups of populations (like elderly and deprived people) should be regarded during designing and constructing biking infrastructures and setting participation rules.
\end{abstract}

Keywords: Attitudes, Barriers, Bicycle Sharing System, Biking, Infrastructures, Perceptions

\section{Introduction}

A sedentary lifestyle is a known risk factor for the recent epidemic of obesity in the world, which is associated with many negative health consequences, mortalities, and costs ${ }^{11,29}$. Regular physical activity has many health benefits: reduces all-cause mortality rates, prevents premature deaths and is essential in the primary and secondary prevention of chronic health problems such as cardiovascular diseases, diabetes, obesity, osteoporosis, stroke and even some cancers (especially colon and breast cancers). It also contributes to the improvement of people's psychological health ${ }^{12}$. Enhancing physical activity in communities is not achievable only through recommendations and needs especial programs and infrastructures ${ }^{2,12,16}$. Since motorized transportation is a contributor to sedentary life Kollenberg ${ }^{13}$, a good strategy to increase physical activity is bringing non-motorized transportation to routine daily lives of people ${ }^{3,4,24}$. Biking and walking are good active alternatives for motor vehicle transportation and their effectiveness in obesity reduction and improvement of the cardiovascular profile has been documented ${ }^{4,7,21}$. Widespread use of bikes for transportation would also result in decreasing traffic loads, accidents and air pollution caused by motor vehicles. Contrary to the public concerns about high probability of traffic injuries among cyclists, in fact, the benefits of using bikes outweigh attributed risks ${ }^{20,22}$. To expand using bikes, there is a need for establishment of biking facilities and infrastructures (like bikeways and bike parking lots) in urban areas, educational programs, social marketing, traffic management and supportive social policies ${ }^{6}$. Some cities in the world have developed "Bicycle Sharing systems (BSS)" for urban transportation

${ }^{*}$ Author for correspondence 
to provide the opportunity of using bikes for public ${ }^{15,25}$. In these systems, people can rent a bike from one station in the city, use it for their routine commute and at the end of their journey they must give it back to another station near their destination ${ }^{9,27}$. BSS is an adaptable, affordable, convenient, healthy and economically beneficial method for transportation that alleviates traffic and related injuries, reduces air pollution and overcomes the problem of low parking room in crowded cities ${ }^{14}$.

The rate of cycling among Iranians is low because of different reasons such as cultural beliefs, higher social acceptance of using cars, limited advertisements, lack of knowledge about biking benefits, low safety of biking paths, barriers for use among women, environmental factors and financial barriers ${ }^{10,23}$. BSS have been established in some cities of Iran ${ }^{2,10,19}$, but despite high expenditures on these projects, they couldn't be as effective as desired ${ }^{16,19}$. In fact, only establishment of infrastructures and BSS does not guarantee biking promotion and people's attitudes and perceptions are important determinants of the usage of these facilities ${ }^{1,5}$. Mashhad at the north east of Iran is the second largest city in Iran and is one of the important religious places among Muslims. Increased numbers of inhabitants besides overload of tourists have made this city overcrowded and caused traffic trouble. This traffic overload is to some extent that has made routine and necessary urban travels annoying challenges and made authorities to seek remedies in this regard. Primarily, biking paths and lanes and later BSS have been developed in Mashhad, but they have not been successful in increasing biking rates and alleviating traffic. Given the failure of biking facilities in Mashhad, we tried to investigate attitudes of some inhabitants toward biking and its infrastructures with regard to their demographic characteristics to find the reasons for such a low adoption of biking in this area. The findings of this study can be useful in detecting points for intervention in order to promote biking and increasing the effectiveness of established infrastructures in this area.

\section{Methods}

This cross-sectional study was carried out during JuneSeptember 2015 in Mashhad. Based on the review of relevant literature, interview with some inhabitants of Mashhad and students and academician of Mashhad University of Medical Sciences, researchers designed a questionnaire for investigating people's perceptions of different aspects of biking and their attitudes toward related infrastructures. Researchers tried to cover all important tips in their questionnaire. A brief review of the questionnaire is available in Table1.

Demographic information also has been included in the questionnaire. In order to obtain a representative sample, equal numbers of questionnaires were distributed in public places of all municipal areas of Mashhad through a multistage sampling. Public places were parks, banks, libraries, mosques and streets and convenience sampling was exerted in each place. Only adult inhabitants (18 years or older) were included in the study. A group of 5 medical students tried to declare the importance of study for all respondents. People completed questionnaires themselves. If respondents were unable to complete forms, interviewers asked each question and completed the

Table 1. A brief review of the questionnaire used in order to determine different attitudes toward biking and related infrastructures

\begin{tabular}{|l|l|l|}
\hline $\begin{array}{l}\text { Questions to assess attitudes } \\
\text { toward different aspects of biking }\end{array}$ & Positive attitudes & Biking is environmentally friendly \\
& Biking has health benefits \\
& Biking alleviates traffic \\
\cline { 3 - 3 } & Negative attitudes & $\begin{array}{l}\text { Biking is an affordable way for transportation (cost-effective) } \\
\text { space and can easily pass through cars in heavy traffic congestions) }\end{array}$ \\
\cline { 3 - 3 } & Biking is tiring \\
\hline & Biking is not safe (leads to accidents and injuries) \\
\hline & Biking takes a lot of time (time-wasting method for transportation) \\
\hline & There is high risk of bike theft in the streets \\
\hline $\begin{array}{l}\text { Questions to assess attitudes toward biking infra- } \\
\text { structures }\end{array}$ & $\begin{array}{l}\text { Presence of biking infrastructures (bike paths, especial parking lots, and } \\
\text { BSS system) is an important factor for biking }\end{array}$ \\
\hline & Rules for participation in BSS are difficult \\
\hline
\end{tabular}


questionnaires. Responses to each question were ranked from 1 to 5 based on Likert scaling. People responded to each question, according to their perception of the importance of that feature: score 1 meant it was the least important feature and 5 meant the most important. Data were extracted from questionnaires and analyzed by SPSS version 11.5. For statistical analysis, we used Spearman Correlation, Mann-Whitney and Kruskal-Wallis tests. Statistically, significant level was considered $\leq 0.05$ in this study.

\section{Results}

A total of 437 Mashhad inhabitants with mean $( \pm S D)$ age of 29.9 ( \pm 11.3 ) years (ranged from 18 to 76$)$ entered the study. Of the participants, $250(57.3 \%)$ were female and $387(88.5 \%)$ were high school graduates or with greater academic degrees. Of respondents, 242 (55.9\%) were married and 191 (44.1\%) were single. The frequencies of different occupational categories among the study population are as follows: $146(34.8 \%)$ students, 113 (27\%) employees, 57 (13.6\%) housewives, 96 (22.9\%) self-employed and 7 (1.7\%) unemployed. Frequencies of prominent methods of transportation among respondents are listed in Table 2.

Car ownership was reported in 240 (55\%) of respondents. With the lack of sufficiently available and reliable answers to the demographic questions that investigated income and economic level in this study, we used car ownership and car price as indicators of respondents' economic status. We considered car owners to be at least in moderate economic status and to separate wealthy people; we set the car price of 500 million Rials (with the exchange rate of 34500 Rials for each Dollar) as the cutoff point. Among car owners 164 (68\%) reported car price of less than 500 million Rials and 76 (32\%) reported owning a car with the price of $\geq 500$ million Rials. Mean ranks for each feature among total population and gender specific ranks are listed in Table 3. Mean ranks for each question, according to other demographic factors (marital status, educational level, job and economic condition) are listed in Tables 4-6.

First five questions of the questionnaire (Table 1), investigated positive attitudes toward biking, and the ranks of these questions were all positively correlated with age. (All p-values were $<0.001$ and $\mathrm{r}=03,0.15,0.15$, 0.2 and 0.16 , respectively).

Questions 6-9, investigated negative attitudes toward biking. Age was correlated with the ranks for "fatigue induction" ( $p=0.04, r=0.1)$ and "low safety" ( $p=0.03, r=$ 0.1 ) of biking; but it was not correlated with the ranks of "wasting time of bikes" ( $p=0.45)$ and "high risk of being theft" ( $p=0.07)$.

Questions 10 and 11 (Table 1), focused on the infrastructures. The given ranks to the "importance of availability of infrastructures" were positively correlated with age ( $\mathrm{p}=0.001, \mathrm{r}=0.17$ ), as well as the given ranks to the "difficulty of BSS participation rules" ( $\mathrm{p}=0.04, \mathrm{r}=0.14$ ).

\section{Discussion}

Mean age of about 30 years and high frequency of university students (about 40\%) among respondents show that most findings of this study can be generalized to young citizens of Mashhad. While $46 \%$ of our study population used private cars and $61 \%$ used public motor vehicles, the rate of biking was only $0.7 \%$. Prevalence of using private cars and public motorized transportation methods in this study is similar to the study of Mokhtari ${ }^{19}$, Isfahan, Iran, but the rate of biking in this study is lower (rate of biking is $0.7 \%$ in our study, compared to $8.37 \%$ in the study of Isfahan). Generally, using bikes for transportation in Iran is lower than many other countries, especially European ones with high adoption of biking ${ }^{1,19}$. Of 240 car owners, just 201 (84\%) reported using their cars for transportation and $16 \%$ of them did not use their private cars and preferred public transportation. Nowadays, having a private car is a criterion of social acceptance in Iran and most people try to have one. Many of private cars are in fact useless at home garages because the owners prefer to commute by public vehicles to avoid stress of driving and wasting time in traffic congestion ${ }^{18}$. With the availability

Table 2. Frequency of prominent methods of urban-transportation among study participants

\begin{tabular}{lllll}
\hline Only Private car, N (\%) & $\begin{array}{l}\text { Private car along with bus, taxi or } \\
\text { metro, N (\%) }\end{array}$ & Only Bus, taxi or metro, N (\%) & Motorcycle, N (\%) & Bike ${ }^{*}$, N (\%) \\
\hline $158(36)$ & $43(10)$ & $223(51)$ & $10(2.3)$ & $3(0.7)$ \\
\hline
\end{tabular}

${ }^{*}$ One of the respondents used bicycle as the only vehicle of transportation and 2 others reported biking besides other methods of transportation 
Table 3. Total and gender-specific mean ranks of attitudes among study participants

\begin{tabular}{lcccc}
\hline Attitudes & $\begin{array}{c}\text { Ranks among } \\
\text { men }(\text { Mean } \pm \text { SD) }\end{array}$ & $\begin{array}{c}\text { Ranks among wom- } \\
\text { en }(\text { Mean } \pm \text { SD) }\end{array}$ & p-Value & $\begin{array}{c}\text { Ranks among total par- } \\
\text { ticipants (Mean } \pm \text { SD) }\end{array}$ \\
\hline Being environmentally friendly & $4.08 \pm .07$ & $4.22 \pm .05$ & 0.28 & $4.17 \pm .95$ \\
Healthy transportation method & $3.97 \pm .07$ & $4.24 \pm .05$ & 0.015 & $4.13 \pm .93$ \\
Reducing traffic & $3.97 \pm .07$ & $4.24 \pm .05$ & 0.015 & $3.96 \pm 1.08$ \\
Low costs & $3.6 \pm .09$ & $3.9 \pm .65$ & 0.03 & $3.77 \pm 1.11$ \\
Flexibility & $3.61 \pm .08$ & $3.89 \pm .06$ & 0.006 & $3.77 \pm 1.03$ \\
Causing tiredness & $4.00 \pm .07$ & $4.00 \pm .06$ & 0.69 & $4 \pm .98$ \\
Not enough safety & $4 \pm .07$ & $3.98 \pm .07$ & 0.96 & $3.99 \pm 1.03$ \\
Wasting time & $3.96 \pm .07$ & $3.90 \pm .06$ & 0.73 & $3.93 \pm .99$ \\
High risk of bike theft & $3.65 \pm .08$ & $3.92 \pm .06$ & 0.018 & $3.80 \pm 1.11$ \\
Presence of infrastructures & $3.74 \pm .09$ & $3.86 \pm .07$ & 0.43 & $3.80 \pm 1.15$ \\
Difficult BSS participation rules & $3.99 \pm .07$ & $4.18 \pm .06$ & 0.04 & $4.10 \pm .99$ \\
\hline
\end{tabular}

Table 4. Mean ranks for attitudes according to marital status and education of study participants

\begin{tabular}{|c|c|c|c|c|c|c|}
\hline \multirow[t]{2}{*}{ Attitudes } & \multicolumn{3}{|c|}{ Marital status } & \multicolumn{3}{|c|}{ Education $^{*}$} \\
\hline & $\begin{array}{l}\text { Ranks in sin- } \\
\text { gles Mean } \pm S D \text { ) }\end{array}$ & $\begin{array}{c}\text { Ranks in married } \\
\text { people }(\text { Mean } \pm S D)\end{array}$ & p-Value & $\begin{array}{l}\text { Ranks among under- } \\
\text { graduates (Mean } \pm \text { SD) }\end{array}$ & $\begin{array}{c}\text { Ranks among grad- } \\
\text { uates (Mean } \pm \text { SD) }\end{array}$ & p-Value \\
\hline $\begin{array}{l}\text { Being environmentally } \\
\text { friendly }\end{array}$ & $3.95 \pm .07$ & $4.34 \pm .05$ & $<0.001$ & $4.30 \pm .14$ & $4.14 \pm .04$ & 0.15 \\
\hline $\begin{array}{l}\text { Healthy transportation } \\
\text { method }\end{array}$ & $3.96 \pm .07$ & $4.27 \pm .05$ & 0.002 & $4.19 \pm .17$ & $4.11 \pm .04$ & 0.12 \\
\hline Reducing traffic & $3.96 \pm .07$ & $4.27 \pm .05$ & 0.002 & $4.17 \pm .13$ & $3.94 \pm .05$ & 0.22 \\
\hline Low costs & $3.6 \pm .08$ & $3.9 \pm .07$ & 0.004 & $4 \pm .17$ & $3.75 \pm .06$ & 0.04 \\
\hline Flexibility & $3.69 \pm .07$ & $3.84 \pm .06$ & 0.15 & $3.71 \pm .15$ & $3.78 \pm .05$ & 0.65 \\
\hline Causing tiredness & $3.92 \pm .07$ & $4.07 \pm .05$ & 0.26 & $4.0 \pm .17$ & $4.01 \pm .05$ & 0.52 \\
\hline Not enough safety & $3.94 \pm .07$ & $4.04 \pm .06$ & 0.37 & $3.83 \pm .18$ & $4.02 \pm .05$ & 0.81 \\
\hline Wasting time & $3.9 \pm .07$ & $3.95 \pm .06$ & 0.75 & $3.93 \pm .16$ & $3.94 \pm .05$ & 0.77 \\
\hline High risk of bike theft & $3.77 \pm .08$ & $3.82 \pm .07$ & 0.54 & $4.12 \pm .18$ & $3.76 \pm .07$ & 0.003 \\
\hline Presence of infrastructures & $3.68 \pm .08$ & $3.92 \pm .07$ & 0.015 & $4.06 \pm .14$ & $3.76 \pm .06$ & 0.11 \\
\hline $\begin{array}{l}\text { Difficult BSS participation } \\
\text { rules }\end{array}$ & $4.02 \pm .07$ & $4.17 \pm .06$ & 0.21 & $4.04 \pm .17$ & $4.12 \pm .05$ & 0.63 \\
\hline
\end{tabular}

${ }^{*}$ Graduates are people with atleast high school certification, undergraduates are people without high school certification

Table 5. Mean ranks of attitudes according to occupations among study participants

\begin{tabular}{|c|c|c|c|c|c|c|}
\hline Attitudes & Employees & $\begin{array}{c}\text { Self-employed } \\
\text { people }\end{array}$ & $\begin{array}{c}\text { Unemployed } \\
\text { people }\end{array}$ & Housewives & $\begin{array}{c}\text { University } \\
\text { students }\end{array}$ & p-Value \\
\hline & $\begin{array}{c}\text { (Mean } \\
\text { ranks } \pm \mathrm{SD})\end{array}$ & $\begin{array}{c}\text { (Mean } \\
\text { ranks } \pm \text { SD) }\end{array}$ & $\begin{array}{c}\text { (Mean ranks } \\
\pm \mathrm{SD})\end{array}$ & $\begin{array}{c}\text { (Mean ranks } \\
\pm \mathrm{SD})\end{array}$ & $\begin{array}{c}\text { (Mean } \\
\text { ranks } \pm \mathrm{SD})\end{array}$ & \\
\hline Being environmentally friendly & $4.32 \pm .08$ & $4.23 \pm .09$ & $4.67 \pm .21$ & $4.45 \pm .09$ & $3.88 \pm .08$ & $<0.001$ \\
\hline Healthy transportation method & $4.23 \pm .07$ & $4.18 \pm .10$ & $4.33 \pm .21$ & $4.36 \pm .10$ & $3.94 \pm .84$ & 0.026 \\
\hline Reducing traffic & $4.10 \pm .09$ & $3.91 \pm .11$ & $3.71 \pm .47$ & $3.89 \pm .09$ & $3.72 \pm .10$ & 0.02 \\
\hline Low costs & $3.92 \pm .10$ & $3.85 \pm .12$ & $4.17 \pm .31$ & $4.12 \pm .11$ & $3.48 \pm .10$ & 0.002 \\
\hline Flexibility & $3.90 \pm .09$ & $3.73 \pm .11$ & $3.33 \pm .33$ & $3.66 \pm .12$ & $3.63 \pm .08$ & 0.04 \\
\hline Causing tiredness & $4.06 \pm .08$ & $4.04 \pm .11$ & $3.28 \pm .56$ & $3.94 \pm .12$ & $3.97 \pm .08$ & 0.65 \\
\hline Not enough safety & $4.02 \pm .09$ & $4.17 \pm .09$ & $3.43 \pm .65$ & $4 \pm .14$ & $3.87 \pm .09$ & 0.30 \\
\hline Wasting time & $3.92 \pm .09$ & $4.02 \pm .10$ & $3.28 \pm .60$ & $3.81 \pm .13$ & $3.93 \pm .08$ & 0.74 \\
\hline High risk of bike theft & $3.88 \pm .09$ & $3.69 \pm .13$ & $3.86 \pm .63$ & $3.98 \pm .15$ & $3.70 \pm .09$ & 0.26 \\
\hline Presence of infrastructures & $3.71 \pm .12$ & $3.97 \pm .11$ & $3.33 \pm .66$ & $4.01 \pm .11$ & $3.66 \pm .09$ & 0.55 \\
\hline Difficult BSS participation rules & $4.16 \pm .08$ & $4.19 \pm .10$ & $4.14 \pm .59$ & $4.07 \pm .14$ & $4.02 \pm .08$ & 0.41 \\
\hline
\end{tabular}


Table 6. Mean ranks of attitudes according to car ownership and car price among study participants

\begin{tabular}{|c|c|c|c|c|c|c|}
\hline \multirow[t]{2}{*}{ Attitudes } & \multicolumn{3}{|c|}{ Car ownership status } & \multicolumn{3}{|c|}{ Car price } \\
\hline & $\begin{array}{l}\text { Not owning a car } \\
\text { (Mean ranks } \pm \text { SD) }\end{array}$ & $\begin{array}{c}\text { Owning a car } \\
\text { (Mean ranks } \pm \text { SD) }\end{array}$ & p-Value & $\begin{array}{l}<500 \text { million Rials } \\
(\text { Mean ranks } \pm \text { SD) }\end{array}$ & $\begin{array}{l}\geq 500 \text { million Rials } \\
(\text { Mean ranks } \pm S D)\end{array}$ & p-Value \\
\hline $\begin{array}{l}\text { Being environmentally } \\
\text { friendly }\end{array}$ & $4.11 \pm .98$ & $4.23 \pm .90$ & 0.25 & $4.15 \pm .96$ & $4.23 \pm .83$ & 0.66 \\
\hline $\begin{array}{l}\text { Healthy transportation } \\
\text { method }\end{array}$ & $4.12 \pm .94$ & $4.14 \pm .91$ & 0.63 & $4.08 \pm .96$ & $4.13 \pm .99$ & 0.48 \\
\hline Reducing traffic & $3.96 \pm 1.15$ & $3.97 \pm 1.04$ & 0.18 & $4.03 \pm 1$ & $3.99 \pm 1$ & 0.69 \\
\hline Low costs & $3.80 \pm 1.09$ & $3.75 \pm 1.14$ & 0.71 & $3.80 \pm 1$ & $3.76 \pm 1$ & 0.69 \\
\hline Flexibility & $3.76 \pm .99$ & $3.78 \pm 1.05$ & 0.63 & $3.70 \pm 1$ & $3.85 \pm 1$ & 0.12 \\
\hline Causing tiredness & $3.91 \pm .98$ & $4 \pm .97$ & 0.02 & $4 \pm .99$ & $3.98 \pm 1$ & 0.81 \\
\hline Not enough safety & $3.90 \pm 1.03$ & $4.9 \pm 1$ & 0.02 & $3.92 \pm 1$ & $4.07 \pm 1$ & 0.16 \\
\hline Wasting time & $3.81 \pm 1.01$ & $4.08 \pm .95$ & 0.01 & $3.96 \pm .89$ & $3.97 \pm 1$ & 0.47 \\
\hline High risk of bike theft & $3.82 \pm 1.05$ & $3.78 \pm 1.18$ & 0.97 & $3.80 \pm 1.19$ & $3.77 \pm 1$ & 0.59 \\
\hline $\begin{array}{l}\text { Presence of infrastruc- } \\
\text { tures }\end{array}$ & $3.70 \pm 1.18$ & $3.91 \pm 1.12$ & 0.04 & $3.68 \pm 1$ & $3.96 \pm 1$ & 0.03 \\
\hline $\begin{array}{l}\text { Difficult BSS participa- } \\
\text { tion rules }\end{array}$ & $4.04 \pm 1.01$ & $4.15 \pm .96$ & 0.30 & $4.10 \pm .98$ & $4.10 \pm 1$ & 0.82 \\
\hline
\end{tabular}

of separate pathways, using public vehicles (bus, taxi, and metro) let people to bypass heavy traffics of private cars and either get rid of the usual trouble of low parking room at their destination.

\section{Conclusion}

In our study, higher socioeconomic status and education did not accompany with higher perceptions of biking benefits. Cultural interventions are the mainstay measures to promote cycling in Iran. Educational programs at academic settings can also be valuable. BSS participation rules should be set based on people's preferences.

\section{Conflict of Interests}

No conflicts of interests.

\section{References}

1. Ahmadi S, Heidari A, Mirfardi A, Mardani Z. Sociological analysis of the relationship between attitudes toward biking and rates of bike using in short urban travels. Journal of Applied Sociology. 2013 Spring; 24(1):123-36. Persian.

2. Campbell ME, Bopp M. An examination of the relationship of interpersonal influences with walking and biking to work. J Public Health Manag Pract. 2013 Nov-Dec; 19(6):521-4.

3. de Geus B, De Smet S, Nijs J, Meeusen R. Determining the intensity and energy expenditure during commuter cycling. Br J Sports Med. 2007 Jan; 41(1):8-12.

4. Dill J, Voros K. Factors affecting bicycling demand: initial survey findings from the Portland, Oregon, region. Transportation Research Record: Journal of the Transportation Research Board. 2007; 2031:9-17.

5. Garrard J, Rose G, Lo SK. Promoting transportation cycling for women: the role of bicycle infrastructure. Prev Med. 2008 Jan; 46(1):55-9.

6. Hataminejad H, Ashrafi Y. The role of bicycle in urban sustainable transportation case study: Bonab City. Human Geography Research Quarterly. 2010; 41(70):45-63. Persian.

7. Jing C, Zhao Z. Research on antecedents and consequences of factors affecting the bike sharing system-Lessons from capital bike share program in Washington, DC. International Conference on Logistics Engineering, Management and Computer Science (LEMCS 2015). 2015 July 29-31; Shenyang, China. Atlantis Press; 2015.

8. Khademolhoseini E, Rahmatu GH, Nejad RG. Investigation of the strategy for reducing load of urban traffic (Study of Shiraz). Amayesh. 2010 Spring; 3(8):1-19. Persian.

9. Afridi AK, Safdar M, Khattak MMAK, Khan A. Health risks of overweight and obesity-An over view. Pakistan Journal of Nutrition. 2003; 2(6):350-60.

10. Khan EB, Ramsey LT, Brownson RC, Heath GW, Howza $\mathrm{EH}$, Powell KE, et al. The effectiveness of interventions to increase physical activity: A systematic review. American Journal of Preventive Medicine. 2002; 22(4):73-107.

11. Kollenberg W, Látková P, Vogt C, Rodríguez A. Active transportation among elementary-aged students: walking or biking to and from school. Proceedings of the 2008 Northeastern Recreation Research Symposium; [Accessed 2016 Apr 8]; Available from: http://www.nrs.fs.fed.us/pubs/ gtr/gtr-p-42papers/03knollenberg-p-42.pdf. p. 15-20. 
12. Kovacs V. Seattle's bicycle Stations: A social and infrastructure support network for tired, wet, and caffeine deprived cyclists, 2014, University of Washington. [Accessed 2016 Apr 8]; Available from: http://hdl.handle.net/1773/25388.

13. Li J, Ren C, Shao B, Wang Q, He M, Dong J, et al. A solution for reallocating public bike among bike stations, in Networking, Sensing and Control (ICNSC). 9th IEEE International Conference 2012 April 11-14. p. 352-5.

14. Malekhoseini A, Dargahi MM, Hajisharifi A, Karaminejad T, Ramezanzade M. Investigating the factors influencing the use of common bicycles in urban transportation: a case study of Haft-Hoz and Madayen Quarters in District 8. Quarterly Geographical Journal of Chashmandaz-e-Zagros. 2012 Spring; 4(11):159-78. Persian.

15. Martin EW, Shaheen SA. Evaluating public transit modal shift dynamics in response to bikesharing: a tale of two US cities. Journal of Transport Geography. 2014; (41):315-24.

16. Mokhtari R. Geographical analysis of the role of bike in the transportation system of Isfahan. Urban-Regional Studies and Research (University of Isfahan). 2011 Summer; 3(9):101-22. Persian.

17. Mueller N, Rojas-Rueda D, Cole-Hunter T, De Nazelle A, Dons E, Gerike R, et al. Health impact assessment of active transportation: a systematic review. Prev Med. 2015 Jul; 76:103-14.

18. Oja P, Vuori I, Paronen O. Daily walking and cycling to work: their utility as health-enhancing physical activity. Patient Educ Couns. 1998 Apr; 33(1 Suppl):S87-94.

19. Pucher J, Dill J, Handy S. Infrastructure, programs, and policies to increase bicycling: An international review. Prev Med. 2010 Jan; 50 Suppl 1: S106-25.

20. Saghayi M, Sadeghi Z. Model for midterm programming for biking. Research and Urban Planning. 2013 Spring; 4(12):95-116. Persian.

21. Shephard RJ. Is active commuting the answer to population health? Sports Med. 2008 Sep; 38(9):751-8.

22. Shimode I, Nakamura F, Wang R. Social costs of private bike and public bike- for bicycle policy evaluation reflecting Japanese situation. Proceedings of International Symposium on City Planning 2013; [Accessed 2016 Apr 8]; Available from: http://www1.cpij.or.jp. p. 1-8.

23. Warburton DER, Nicol CW, Bredin SSD. Health benefits of physical activity: the evidence. Canadian Medical Association Journal. 2006; 174(6):801-9.

24. Wareham NJ, Sluijs EMF, Ekelund U. Physical activity and obesity prevention: a review of the current evidence. Proceedings of the Nutrition Society. 2005; 64(2):229-47.

25. Zeng XM, Zhang YH. Bike sharing system in Foshan: planning \& practice. In: Applied Mechanics and Materials. Trans Tech Pub. 2012 May; 178-181:1738-43. 